\title{
PERAN PEMERINTAH DAERAH DI DALAM MELINDUNGI HAK ANAK DI INDONESIA
}

\author{
Darmini Roza, Laurensius Arliman S \\ Fakultas Hukum Universitas Ekaskti, STIH Padang \\ J1. Veteran Dalam No.26B, Padang Pasir, Kota Padang, \\ Jl. Gang Mesid Baiturahman No.40, Kota Padang \\ darminirozaa@gmail.com, laurensiusarliman@gmail.com
}

\begin{abstract}
Local government has a very vital role in the protection of children. This is stated in the articles of the Child Protection Act. In realizing the governance of the fulfillment of children's rights by the Regional Government must be fully realized and implemented properly. Decent City Children are the dream of every child, because the child will be raised properly and properly. Local Government as a government in direct contact with the life of children, should be more active and more critical, to voice the rights of children. Managing the fulfillment of children's rights by the Regional Government should be overseen by an institution that focuses on protecting, protecting, monitoring and monitoring the rights of children. Understanding of sustainable child protection needs to be taught from an early age to the community, because if people are taught early on about sustaining child protection, then child protection in Indonesia will not stop.
\end{abstract}

Keywords: Local government; Rights of the Child; Indonesia.

\begin{abstract}
Abstrak
Pemerintah Daerah memiliki peran yang sangat vital didalam perlindungan anak. Hal ini tertuang didalam pasal-pasal Undang-Undang Perlindungan Anak. Didalam mewujudkan tata kelola pemenuhan hak anak oleh Pemerintah Daerah haruslah benar-benar direalisasikan dan dijalankan dengan semestinya. Kota Layak Anak merupakan impian dari setiap anak, karena anak akan dibesarkan secara layak dan semestinya. Pemerintah Daerah sebagai pemerintah yang bersentuhan lansung dengan kehidupan anak, harusnya lebih aktif dan lebih kritis, untuk menyuarakan hak-hak anak. Menata kelola pemenuhan hak anak oleh Pemerintah Daerah harus diawasi sebuah lembaga sendiri yang fokus untuk melindungi, menjaga, memantau dan mengawasi hak anak. Penanaman pemahaman perlindungan anak berkelanjutan sangatlah perlu diajarkan sejak dini kepada masyarakat, karena apabila sejak dini masyarakat diajarkan memahami perlindungan anak secara berkelanjutan, maka perlindungan anak di Indonesia tidak akan berhenti.
\end{abstract}

Kata Kunci: Pemerintah Daerah; Hak Anak; Indonesia.

\section{A. Pendahuluan}

Di setiap negara, hak anak telah di atur dalam Undang-Undang dalam hal ini tidak terkecuali di Indonesia(Qamar 2015). Apakah hak anak sudah berjalan dengan semestinya? pertanyaan yang singkat untuk di jawab antara sudah atau memang belum. Anak yang seharusnya mendapatkan kasih sayang dari kedua orangtuanya, tapi bagaimana dengan fenomena yang terjadi dalam masyarakat pada saat ini? Banyak bayi, anak balita di buang oleh kedua orangtuanya atau di titipkan ke panti asuhan. Bahkan yang sering terjadi yaitu penjualanan anak di bawah umur dan menelantarkan anaknya, walupun sudah tinggal satu atap. Apakah itu termasuk pelanggaran atas hak untuk kelangsungan hidup dan tumbuh kembang anak? Dalam fenomena lain menyebutkan anak-anak sering di jadikan obyek eksploitasi oleh orangtuanya. Misalnya saja menyuruh anaknya bekerja daripada melanjutkan 
pendidikan(Arliman 2017). Memang secara kodratnya kewajiban anak yaitu membantu orangtua, tetapi jika orangtua itu masih bisa bekerja lalu kenapa anak yang dijadikan sebagai obyek eksploitasi? Bahkan sering ditemui dijalanan anak balita yang dibawa oleh orangtuanya untuk mengemis. Bagaimana peran negara dalam meminimalisir eksploitasi anak agar anak dapat terpenuhi hak-haknya? Fenomena dalam penegakan hukum juga sangat menjadi sorotan, akibat dari pergaulan yang salah dan tidak adanya kontrol dari orang tua, membuat anak melalukan pelanggaran bahkan tindak pidana. Bagaimana peran negara dalam memenuhi hak anak yang terbukti melakukan tindak pidana? Apakah anak akan mudah bergabung kedalam masyarakat dan menjadi seorang dewasa yang ideal? Bagaimana penerapan hukum oleh penegak hukum terhadap anak sebagai pelaku tindak pidana sudah sesuai ketentuan?

Makna equality before the law sebagai suatu mata rantai antara hak dan kewajiban haruslah berfungsi menurut kedudukannya masing-masing(Rochaeti 2015). Sehingga makna kesamaan di hadapan hukum memberikan pengertian bahwa setiap warga negara harus diperlakukan adil oleh aparat penegak hukum dan pemerintah. Didalam Pasal 23 Ayat 1 Undang-Undang Nomor 17 Tahun 2016 tentang Perubahan Kedua Atas Undang-Undang Nomor 23 Tahun 2002 tentang Perlindungan Anak (UU Perlindungan Anak) menyebutkan bahwa Negara, Pemerintah, dan Pemerintah Daerah menjamin perlindungan, pemeliharaan, dan kesejahteraan Anak dengan memperhatikan hak dan kewajiban Orang Tua, Wali, atau orang lain yang secara hukum bertanggung jawab terhadap Anak. Namun Selama ini yang terlihat Pemerintah Daerah kurang terlihat dalam memenuhi pemuhan hak anak(S 2017). Idealnya Pemerintah Daerah sebagai perpanjangan pemerintah pusat(Adam 2012), yang bersentuhan lansung dengan anak, harus lebih kritis dalam menangani hak anak tersebut. Banyak kasuskasus pelanggaran hak anak yang terjadi di daerah, nyatanya masih menunggu kinerja yang ditangani lansung dari pemerintah pusat. Pemerintah Daerah sepertinya belum mempunyai perhatian secara sungguh- sungguh dan belum ada kebijakan yang baik terhadap perlindungan hak-hak anak serta belum menjadi skala perioritas dalam pembangunan daerah(Asshiddiqie 2006).

Seperti makna perumpamaan buah jatuh tidak pernah jauh dari pohon atau air cucuran atap jatuhnya kepelimbahan, dapat dimaknai bahwa tingkah laku dari anak merupakan turunan dari sikap atau perilaku orangtua yang dengan mudah ditiru oleh anak ataupun bagaimana pengaruh didikan orangtua kepada anak setiap harinya. Seharusnya anak yang lahir, diharapkan bukan menjadi preman, pencuri, pencopet ataupun gepeng (gelandangan dan pengemis), tetapi diharapkan menjadi anak yang berguna bagi keluarga di masa datang, yaitu menjadi tulang punggung keluarga, pembawa nama baik keluarga, bahkan juga harapan nusa dan bangsa. Perkembangan hidup seorang anak menjadi manusia dewasa, tidak terlepas dari tahap pencarian jati diri, pencarian jati diri seorang anak merupakan inti dari pola pikir anak kedepan dalam melakukan tindakantindakannya. Dalam tahap ini dipengaruhi oleh mentalnya, kadang anak mudah terpengaruh dengan situasi dan kondisi lingkungan disekitarnya. Sehingga jika lingkungan tempat anak berada tersebut buruk, dapat berpengaruh pada tindakan yang dapat melanggar hukum. Hal itu tentu saja dapat merugikan dirinya sendiri, keluarga dan masyarakat.

Anak memiliki sistem penilaian kanakkanak yang menampilkan martabat anak sendiri dan kriteria norma sendiri, sebab sejak lahir anak sudah menampakan ciri-ciri dan tingkah laku karakteristik yang mandiri, memiliki keperibadian yang khas dan unik. Hal ini disebabkan oleh karena taraf perkembangan anak itu memang selalu berlainan dengan sifat-sifatnya dan ciricirinya, dimulai pada bayi, remaja, dewasa dan usia lanjut, akan berlainan psikis maupun jasmaninya. Anak mempunyai hak yang sama dengan warga negara lainnya, yang harus dilindungi dan dihormati oleh setiap warga Negara dan Negara. Setiap Negara dimanapun di dunia ini wajib memberikan perhatian serta perlindungan yang cukup terhadap hak-hak anak. Sampai saat ini problematika anak belum menarik masyarakat dan pemerintah(Halili 2015). 
Sangat diperlukan pengakuan dan perlindungan hak-hak anak yang bertujuan agar mereka dapat tumbuh dan berkembang secara wajar sebagai anak, serta menghindari sejauh mungkin dari berbagai macam ancaman dan gangguan yang mungkin datang dari lingkungannya, maupun dari anak itu sendiri. Karena perlindungan hukum memang sangat dibutuhkan oleh siapa saja, kapan saja dan dimana saja, termasuk anak-anak.

Anak telah menjadi sasaran kepentingan bagi banyak kalangan, termasuk untuk tujuan komersial yang merugikan kepentingan terbaik bagi anak. Betapa saat ini telah terjadi semacam jaringan yang memanfaatkan anak objeknya. Anak dijadikan objek untuk diperjualbelikan, objek kekerasan, menjadi alat oleh orang dewasa tertentu untuk mencari nafkah dijalan-jalan sebagai anak jalana, dan sebagainya. Perlakuan kekerasan terhadap anak itu seringkali justru terjadi dilingkungan sekitar anak itu sendiri, dimana seharusnya anak memperoleh perlindungan. Lihat saja pada ini kasus kelalaian terhadap perlindungan anak: 1) semakin meningkatnya anak yang disuruh orangtuanya untuk bekerja di jalanan; 2) anak yang dipaksa bekerja untuk memenuhi kebutuhan keluarga; 3) kekerasan seksual terhadap anak; 4) anak diperjualbelikan (eksploitasi) untuk pemuas seks dan kasus lainnya yang tidak menguntungkan anak(Ardhyanto 2015). Itulah gambaran yang kurang menggemberikan bagi potret anak di Indonesia, pada masa ini.

Berdasarkan kasus-kasus yang dipaparkan, sangat terlihat sekali baik Penegak Hukum dan Orang Tua mengabaikan hak-hak anak yang seharusnya mereka dapatkan. Disini juga terlihat, Pemerintah Daerah belum ikut andil atau campur tangan untuk menengahi kasus yang bersentuhan lansung dengan anak. Maka penulis tertarik untuk membahas lebih dalam tentang peran Pemerintah Daerah terhadap pelaksanaan hak-hak anak yang tercantum dalam ketentuan perundang-undangan tentang perlindungan terhadap hak-hak anak dan didalam konvensi hak anak secara berkelanjutan. Bertitik tolak kepada latar belakang sebagaimana diungkapkan di atas, maka yang menjadi masalah dalam tulisan ini adalah: 1) bagaimana peran pemerintah daerah melindungi hal anak? 2) bagaimana mewujudkan tata kelola pemenuhan hak anak oleh pemerintah daerah? 3) menggagas perlindungan anak yang berkelanjutan oleh pemerintah daerah? Penelitian ini adalah peneltian yuridis normatif dengan memakai Pendekatan perundang-undangan(Bedner et al. 2012), untuk menelaah semua regulasi yang bersangkut paut dengan isu hukum terkait peran pemerintah daerah terkait perlindungan anak.

\section{B. Hasil dan Pembahasan}

1. Peran Pemerintah Daerah didalam Undang-Undang Nomor 17 Tahun 2016 Perubahan Kedua Atas UndangUndang Nomor 23 Tahun 2002 Tentang Perlindungan Anak.

Pemerintahan Daerah seperti tertuang didalam pasal 1 angka 1 Undang-undang Nomor 23 Tahun 2014 Tentang Pemerintahan Daerah (UU Pemda), adalah penyelengaraan urusan pemerintahan oleh pemerintah daerah dan dewan perwakilan rakyat menurut asas otonomi dan tugas pembantuan dengan prinsip otonomi seluas-luasnya dalam sistem dan prinsip Negara Kesatuan Republik Indonesia sebagaimana dimaksud dalam Undang-Undang Dasar Negara Republik Indonesia Tahun 1945. Sedangkan di angka 2 menjelaskan bahwa Pemerintah Daerah adalah kepala daerah sebagai unsur penyelenggara Pemerintahan Daerah yang memimpin pelaksanaan urusan pemerintahan yang menjadi kewenangan daerah otonom(Fahmiron 2017).

Didalam pasal 1 angka 12 dan 19 UU Perlindungan Anak menjelaskan bahwa Hak Anak adalah bagian dari hak asasi manusia (HAM) yang wajib dijamin, dilindungi, dan dipenuhi oleh Orang Tua, Keluarga, Masyarakat, Negara, Pemerintah, dan Pemerintah Daerah. Pemerintah Daerah disini adalah Gubernur, Bupati dan Walikota serta perangkat daerah sebagai unsur penyelengara pemerintahan. Hal tersebut secara tegas menjelaskan bagaimana kewajiban dari Pemerintah Daerah untuk melindungi hakhak a nak terutam a d idala m perkembangannya menuju dewasa, agar kelak menjadi orang yang berguna bagi Keluarga, Masyarakat, Pemerintah Daerah dan Negara. Seperti bunyi pasal 20 UU 
Perlindungan Anak bahwa Negara, Pemerintah, Pemerintah Daerah, Masyarakat, Keluarga dan Orang Tua atau Wali berkewajiban dan bertanggung jawab terhadap penyelangaraan perlindungan anak.

Beberapa hak anak yang harus dilindungi sebagaimana dimaksud dalam Pasal 65 Undang-Undang Nomor 39 Tahun 1999 tentang Hak Asasi Manusia bahwa setiap anak berhak untuk memperoleh perlindungan dari kegiatan eksploitasi dan pelecehan seksual, penculikan, perdagangan anak, serta dari berbagai bentuk penyalahgunaan narkotika, psikotropika, dan zat adiktif lainnya. Kebijakan kriminal sebagaimana adalah suatu usaha yang rasional dari masyarakat dalam menanggulangi kejahatan, dengan mengacu pada pendapat Marc Ancel sebagai the rational organization of the control of crime by society(Rezah 2015).

Prinsip-prinsip Perlindungan Anak yang wajib untuk dilindungi dan dijalankan oleh Pemerintah Darerah sesuai amandat dari UU Perlindungan Anak, adalah: a) Anak tidak dapat berjuang sendiri, salah satu prinsip yang digunakan dalam perlindungan anak adalah: anak itu adalah modal utama kelansungan hidup manusia, bangsa, dan keluarga, untuk itu hak-haknya harus dilindungi. Anak tidak dapat melindungi sendiri hak-haknya, banyak pihak yang mempengaruhi kehidupannya; b) Kepentingan terbaik anak (the best interest of the child), agar perlindungan anak dapat diselenggarakan dengan baik, dianut prinsip yang menyatakan bahwa kepentingan terbaik anak harus dipandang sebagai of paramount importence (memperoleh prioritas tertinggi) dalam setiap keputusan menyangkut anak. Tanpa prinsip ini perjuangan untuk melindungi anak akan mengalami banyak batu sandungan; c) Ancangan daur kehidupan (life-circle approach), perlindungan anak mengacu pada persamaan pada pemahaman bahwa perlindungan anak harus dimulai sejak dini dan terus menerus. Janin yang berada dalam kandungan perlu dilindungi dengan gizi termasuk yodium dan kalsium yang baik melalui ibunya. Jika ia telah lahir, maka diperlukan air susu ibu (ASI) dan pelayanan kesehatan primer dengan memberikan pelayanan imunisasi dan lain-lain, sehingga anak terbebas dari berbagai mungkin kecacacatan dan penyakit; d) Lintas Sektoral, nasib anak tergantung dari berbagai faktor, baik yang makro maupun mikro, yang lansung maupun tidak lansung (Widiantari 2017). Kemiskinan, perencanaan kota dan segala penggusuran, sistem pendidikan yang menekankan hafalan dan bahan-bahan yang tidak relevan, komunitas yang penuh dengan ketidakadilan, dan sebagainya dapat ditangani oleh sektor, terlebih keluarga atau anak itu sendiri. Perlindungan terhadap anak adalah perjuangan yang membutuhkan sumbagan semua orang di semua tingkatan.

Pasal 21 UU Perlindungan Anak menjelaskan bahwa Pemerintah Daerah berkewajiban dan bertangung jawab untuk menghormati pemenuhan hak anak tanpa membedakan suku, agama, ras, golongan, jenis kelamin, etnik, budaya dan bahasa, status hukum, urutan kelahiran, dan kondisi fisik dan/atau mental. Untuk menjamin pemenuhan Hak Anak Pemerintah Daerah berkewajiban untuk memenuhi, melindungi, dan menghormati Hak Anak, Pemerintah Daerah juga berkewajiban dan bertanggung jawab dalam merumuskan dan melaksanakan kebijakan di bidang penyelenggaraan Perlindungan Anak. Untuk menjamin pemenuhan Hak Anak dan melaksanakan kebijakan sebagaimana dimaksud diatas maka, Pemerintah Daerah berkewajiban dan bertanggung jawab untuk melaksanakan dan mendukung kebijakan nasional dalam penyelenggaraan Perlindungan Anak di daerah. Kebijakan ini dapat diwujudkan melalui upaya daerah membangun kabupaten/kota layak Anak(Statistik 2015). Terhadap ketersediaan sumber daya manusia dalam penyelenggaraan Perlindungan Anak Pemerintah Daerah berkewajiban dan bertanggung jawab memberikan dukungan sarana, prasarana, dan ketersediaan (yang dimaksud dengan "dukungan sarana dan prasarana", misalnya sekolah, lapangan bermain, lapangan olahraga, rumah ibadah, fasilitas pelayanan kesehatan, gedung kesenian, tempat rekreasi, ruang menyusui, tempat penitipan Anak, termasuk optimalisasi dari unit pelaksana teknis penyelenggaraan Perlindungan Anak yang ada di daerah), seperti yang dijelaskan didalam Pasal 22 UU Perlindungan Anak. Pasal 23 dan 24 UU Perlindungan Anak menjelasakan peran 
Pemerintah Daerah, didalam perlindungan anak lebih lanjut yaitu: a) Pemerintah Daerah menjamin perlindungan, pemeliharaan, dan kesejahteraan Anak dengan memperhatikan hak dan kewajiban Orang Tua, Wali, atau orang lain yang secara hukum bertanggung jawab terhadap Anak; b) Pemerintah Daerah mengawasi penyelenggaraan Perlindungan Anak; dan c) Pemerintah Daerah menjamin Anak untuk mempergunakan haknya dalam menyampaikan pendapat sesuai dengan usia dan tingkat kecerdasan Anak.

Didalam menjalankan tanggung jawab dan kewajibannya pemerintah daerah harus melaksanakan pengawasan lansung terhadap perlindungan hak anak, selain pengawasan perlindungan hak anak yang tertuang dari tanggung jawab dan kewajiban dari pemerintah daerah yang telah dijelaskan diatas, pengawasan pemerintah daerah juga tekait dalam hal berikut ini yaitu:

a) Pemerintah Daerah melakukan bimbingan dan pengawasan terhadap pelaksanaan pengangkatan Anak (Pasal 41) yang selanjutnya diatur dengan Peraturan Pemerintah (Pasal 41 A);

b) Pemerintah Daerah menjamin Perlindungan Anak dalam memeluk agamanya yang meliputi pembinaan, pembimbingan, dan pengamalan ajaran agama bagi Anak (Pasal 43);

c) Pemerintah Daerah wajib menyediakan fasilitas dan menyelenggarakan upaya kesehatan yang komprehensif bagi Anak agar setiap Anak memperoleh derajat kesehatan yang optimal sejak dalam kandungan (Pasal 44);

d) Pemerintah Daerah wajib memenuhi tanggung jawab menjaga kesehatan Anak dan merawat Anak sejak dalam kandungan apabila Orang Tua dan Keluarga yang tidak mampu melaksanakan tanggung jawab tersebut (Pasal 45);

e) Pemerintah Daerah wajib melindungi Anak dari perbuatan yang mengganggu kesehatan dan tumbuh kembang Anak, terhadap hal ini Pemerintah Daerah harus melakukan aktivitas yang melindungi Anak (Pasal 45 B);

f) Pemerintah Daerah wajib mengusahakan agar Anak yang lahir terhindar dari penyakit yang mengancam kelangsungan hidup dan/atau menimbulkan kecacatan (Pasal 46);

g) Pemerintah Daerah wajib melindungi Anak dari upaya transplantasi organ tubuhnya (Pemerintah Daerah wajib melindungi Anak dari perbuatan: a) pengambilan organ tubuh Anak dan/atau jaringan tubuh Anak tanpa memperhatikan kesehatan Anak; b) jual beli organ dan/atau jaringan tubuh Anak; c) penelitian kesehatan yang menggunakan Anak sebagai objek penelitian tanpa seizin Orang Tua dan tidak mengutamakan kepentingan yang terbaik bagi Anak) untuk pihak lain (Pasal 47);

h) Pemerintah Daerah wajib menyelenggarakan pendidikan dasar minimal 9 (sembilan) tahun untuk semua Anak (Pasal 48);

i) Pemerintah Daerah wajib memberikan kesempatan yang seluas-luasnya kepada Anak untuk memperoleh pendidikan (Pasal 49);

j) Pemerintah Daerah bertanggung jawab untuk memberikan biaya pendidikan dan/atau bantuan cuma-cuma atau pelayanan khusus bagi Anak dari Keluarga kurang mampu, Anak Terlantar, dan Anak yang bertempat tinggal di daerah terpencil (Pasal 53);

k) Pemerintah Daerah wajib menyelenggarakan pemeliharaan, perawatan, dan rehabilitasi sosial Anak terlantar, baik di dalam lembaga maupun di luar lembaga (Penyelenggaraan pemeliharaan dapat dilakukan oleh lembaga masyarakat, Untuk menyelenggarakan pemeliharaan dan perawatan Anak terlantar, lembaga pemerintah dan lembaga masyarakat dapat mengadakan kerja sama dengan berbagai pihak yang terkait. Dalam hlm penyelenggaraan pemeliharaan dan perawatan pengawasannya dilakukan o l e h k e m e teria $n$ y a $\mathrm{g}$ menye lenggarakan urusan pemerintahan di bidang sosial) (Pasal 55);

1) Pemerintah Daerah dalam menyelenggarakan pemeliharaan dan perawatan wajib mengupayakan dan 
membantu Anak, agar Anak dapat: a) berpartisipasi; b) bebas menyatakan pendapat dan berpikir sesuai dengan hati nurani dan agamanya; c) bebas menerima informasi lisan atau tertulis sesuai dengan tahapan usia dan perkembangan Anak; d) bebas berserikat dan berkumpul; e) bebas beristirahat, bermain, berekreasi, berkreasi, dan berkarya seni budaya; dan memperoleh sarana bermain yang memenuhi syarat kesehatan dan keselamatan. (Pasal 56);

m) Pemerintah Daerah wajib menyediakan tempat penampungan, pemeliharaan, dan perawatan Anak Terlantar yang bersangkutan (Pasal 58);

n) Pemerintah Daerah berkewajiban dan bertanggung jawab untuk memberikan Perlindungan Khusus (Perlindungan Khusus tersebut kepada Anak dengan kriteria sebagai berikut: a) Anak dalam situasi darurat; b) Anak yang berhadapan dengan hukum; c) Anak dari kelompok minoritas dan terisolasi; d) Anak yang dieksploitasi secara ekonomi dan/atau seksual; e) Anak yang menjadi korban penyalahgunaan narkotika, alkohol, psikotropika, dan zat adiktif lainnya; f) Anak yang menjadi korban pornografi; g) Anak dengan HIV/AIDS; h) Anak korban penculikan, penjualan, dan/atau perdagangan; i) Anak korban Kekerasan fisik dan/atau psikis; j) Anak korban kejahatan seksual; k) Anak korban jaringan terorisme; 1) Anak Penyandang Disabilitas; m) Anak korban perlakuan salah dan penelantaran; n) Anak dengan perilaku sosial menyimpang; dan o) Anak yang menjadi korban stigmatisasi dari pelabelan terkait dengan kondisi Orang Tuanya. Penjelasan lebih rinci selanjutnya bisa dilihat didalam Pasal 59 A, Pasal 60, Pasal 64, Pasal 65, Pasal 66, Pasal 67, Pasal 67A, Pasal 67B, Pasal 67C, Pasal 68, Pasal 69, Pasal 69 A, Pasal 69 B, Pasal 70, Pasal 71, Pasal 71A, Pasal 71B, Pasal 71C, Pasal 71D.) kepada Anak (Pasal 59);

o) Pemerintah Daerah bertanggung jawab menyediakan dana penyelenggaraan (Pendanaan penyelenggaraan
Perlindungan Anak bersumber dari: a) Anggaran Pendapatan dan Belanja Negara; b) Anggaran Pendapatan dan Belanja Daerah; dan c) sumber dana lain yang sah dan tidak mengikat, sumber dana lain yang sah dan tidak mengikat dikelola sesuai dengan ketentuan peraturan perundang-undangan.) Perlindungan Anak (Pasal 71E);

2. Mewujudkan Tata Kelola Pemenuhan Hak Anak oleh Pemerintah Daerah.

Indonesia telah meratifikasi Konvensi Hak Anak sejak 5 September 1990. Hal ini merupakan komitmen Indonesia dalam menghormati dan memenuhi hak anak. Komitmen ini tertuang dalam UndangUndang Dasar 1945 Pasal 28 B (2), dan operasionalnya pada UU PA Untuk mentransformasikan hak anak ke dalam proses pembangunan, pemerintah mengembangkan kebijakan Kota Layak Anak. Kota Layak Anak merupakan istilah yang diperkenalkan pertama kali oleh Kementerian Negara Pemberdayaan Perempuan tahun 2005 melalui Kebijakan Kota Layak Anak. Karena alasan untuk mengakomodasi pemerintahan kabupaten, belakangan istilah Kota Layak Anak menjadi Kabupaten/Kota Layak Anak dan kemudian disingkat menjadi KLA. Dalam Kebijakan tersebut digambarkan bahwa KLA merupakan upaya pemerintahan kabupaten/kota untuk mempercepat implementasi Konvensi Hak Anak (KHA) dari kerangka hukum ke dalam definisi, strategi, dan intervensi pembangunan seperti kebijakan, institusi, dan program yang layak anak(Ardiansyah, Ferdricka Nggeboe 2015). Kota Layak Anak dan atau Kota Ramah Anak kadang-kadang kedua istilah ini dipakai dalam arti yang sama oleh beberapa ahli dan pejabat dalam menjelaskan pentingnya percepatan implementasi Konvensi Hak Anak ke dalam pembangunan sebagai langkah awal untuk memberikan yang terbaik bagi kepentingan anak.

Tujuan dari inisitif KLA adalah untuk mengintegrasikan hak-hak anak ke dalam pembangunan kabupaten/kota; untuk melaksanakan kebijakan kabupaten/kota yang layak anak; untuk memobilisasi dan mengintegrasikan sumberdaya manusia, 
keuangan, sarana, prasarana dan metode yang ada pada pemerintah, masyarakat dan dunia usaha dalam rangka menciptakan kabupaten/kota yang dapat memenuhi hakhak anak; untuk menyusun perencanaan dan melaksanakan strategi, program, kegiatan, dan anggaran yang responsif terhadap kebutuhan dan kepentingan terbaik bagi anak; untuk memperkuat peran pemerintah kabupaten/kota, dalam menyatukan tujuan pembangunan daerah di bidang perlindungan anak; untuk mempercepat kemampuan keluarga, masyarakat, dunia usaha di pemerintahan kabupaten/kota dalam mewujudkan kesejahteraan dan perlindungan anak; dan untuk menyusun dan memantau kerangka kebijakan pemerintah kabupaten/kota yang layak anak dengan mekanisme berkelanjutan(Fauzan 2010).

Pemekaran kabupaten dan kota merupakan buah dari otonomi daerah. Gejala ini sudah terasa sejak berlakunya UndangUndang Otonomi Daerah tahun 2001 (Kurniawan 2016). Tujuan akhir dari pemekaran ini adalah diarahkan untuk mempercepat terwujudnya kesejahteraan masyarakat melalui peningkatan, pelayanan, pemberdayaan, dan peran serta masyarakat, serta peningkatan daya saing daerah dengan memperhatikan prinsip demokrasi, pemerataan, keadilan, keistimewaan dan kekhususan suatu daerah dalam sistem Negara Kesatuan Republik Indonesia. Makna dari tujuan akhir ini tersirat bahwa perlindungan anak menjadi salah satu urusan wajib yang diserahkan oleh pemerintah ke pemerintah kabupaten dan kota akan semakin terwujud. KLA adalah kota yang menjamin hak setiap anak sebagai warga kota. Sebagai warga kota, berarti anak: a) keputusannya mempengaruhi kotanya; b) dapat mengekspresikan pendapatnya mengenai kota yang mereka inginkan; c) dapat berperan serta dalam kehidupan keluarga, komuniti, dan sosial; d) dapat mengakses pelayanan dasar seperti kesehatan dan pendidikan; e) dapat mengakses air minum segar dan tinggal di lingkungan dengan sanitasi yang baik; f) terlindungi dari eksploitasi, kekerasan dan penelantaran; g) merasa aman berjalan di jalan; h) dapat bertemu dan bermain dengan temannya; i) hidup di lingkungan yang bebas polusi; j) berperan serta dalam kegiatan budaya dan sosial; dan k) secara seimbang dapat mengakses setiap pelayanan, tanpa memperhatikan suku bangsa, agama, kekayaan, gender, dan kecacatan.

Dari uraian tersebut, tergambar bahwa ada tantangan besar untuk mempercepat implementasi hak anak di tingkat kabupaten/kota, provinsi, pada masa kini dan masa datang. Padahal masalah bukan hanya anak, namun, jika kita tidak segera berinisatif, dikhawatirkan kepentingan terbaik bagi anak terabaikan. Artinya, hak tumbuh dan berkembang mereka kurang optimal, yang akan berujung pada hilangnya satu generasi bangsa. Selain itu kunci sukses untuk mewujudkan kota layak bagi anak adalah adanya keikhlasan dan ketulusan orang dewasa mengutamakan kepentingan terbaik anak.

Untuk efektivitas pengawasan penyelenggaraan Perlindungan Anak diperlukan lembaga independen yang diharapkan dapat mendukung Pemerintah dan Pemerintah Daerah dalam penyelenggaraan Perlindungan Anak. Pasal 74 UU Perlindungan Anak angka 1 menyatakan bahwa Dalam rangka meningkatkan efektivitas pengawasan penyelenggaraan pemenuhan Hak Anak, dengan UndangUndang ini dibentuk Komisi Perlindungan Anak Indonesia yang bersifat independen. Dan didalam angka 2 lebih menjabarkan peran dari Pemerintah Daerah yang diberi kewenangan yang dinyatakan sebagai berikut bahwa, dalam hal diperlukan, Pemerintah Daerah dapat membentuk Komisi Perlindungan Anak Daerah atau lembaga lainnya yang sejenis untuk mendukung pengawasan penyelenggaraan Perlindungan Anak di daerah.

Bandingkan dengan Lembaga Perlindungan Anak sebagai wahana masyarakat yang independen guna ikut memperkuat mekanisme nasional dan internasional dalam mewujudkan situasi dan kondisi yang kondusif bagi pemantauan, pemajuan dan perlindungan hak anak dan solusi bagi permasalahan anak yang timbul, dimana ini lahir dari prakarsa Departemen Sosial Republik Indonesia, Tokoh Masyarakat, Perguruan Tinggi, Organisasi Non-Pemerintah dan Pemerintah, Media Massa dan kalangan Profesi serta dukungan 
Badan Dunia urusan anak-anak (UNICEF) melalui Forum Nasional Perlindungan Anak yang Pertama (I) tanggal 26 Oktober 1998, dibentuklah Komisi Nasional Perlindungan Anak yang selanjutnya disebut Lembaga Perlindungan Anak pada tahun 2017 (Hidayati 2014). Visi: Terwujudnya kondisi perlindungan anak yang optimum dalam mewujudkan anak yang handal, berkualitas dan berwawasan menuju masyarakat yang sejahtera dan mandiri, dan Misi: Melindungi anak dari setiap orang dan/atau lembaga yang melanggar hak anak, serta mengupayakan pemberdayaan keluarga dan masyarakat agar mampu mencegah terjadinya pelanggaran hak anak, Mewujudkan tatanan kehidupan yang mampu memajukan dan melindungi anak dan hak-haknya serta mencegah pelanggaran terhadap anak sendiri, dan Meningkatkan upaya perlindungan anak melalui peningkatan kesadaran, pengetahuan dan kemampuan masyarakat serta meningkatkan kualitas lingkungan yang memberi peluang, dukungan dan kebebasan terhadap mekanisme perlindungan. Peran Lembaga Perlindungan Anak: a) melakukan pemantauan dan pengembangan perlindungan anak; b) melakukan advokasi dan pendampingan pelaksanaan hak-hak anak; c) menerima pengaduan pelanggaran hak-hak anak; melakukan kajian strategis terhadap berbagai kebijakan yang menyangkut kepentingan terbaik bagi anak; d) melakukan koordinasi antar lembaga, baik tingkat regional, nasional maupun international; memberikan pelayanan bantuan hukum untuk beracara di pengadilan mewakili kepentingan anak; e) melakukan rujukan untuk pemulihan dan penyatuan kembali anak; dan f) menyelenggarakan pendidikan dan pelatihan, pengenalan dan penyebarluasan informasi tentang hak anak. Sedangkan Lembaga Perlindungan Anak mempunyai fungsi: a) melakukan pengumpulan data, informasi dan investigasi terhadap pelanggaran hak anak; b) melakukan kajian hukum dan kebijakan regional dan nasional yang tidak memihak pada kepentingan terbaik anak; memberikan penilaian dan pendapat kepada pemerintah dalam rangka mengintegrasikan hak-hak anak dalam setiap kebjijakan; c) memberikan pendapat dan laporan independen tentang hukum dan kebijakan berkaitan dengan anak; d) menyebarluaskan, publikasi dan sosialisasi tentang hak-hak anak dan situasi anak di indonesia; e) menyampaikan pendapat dan usulan tentang pemantauan pemajuan dan kemajuan, dan perlindungan hak anak kepada parlemen, pemerintah dan lembaga terkait; f) mempunyai mandat untuk membuat laporan alternatif kemajuan perlindungan anak di tingkat nasional; dan melakukan perlindungan khusus. Dari penjelasan tersebut penulis merasa Pemerintah Daerah sudah terbantu dengan adanya Lembaga Perlindungan Anak, dan Komisi Perlindungan Anak Daerah dan Lembaga Sosial lainya, yang juga fokus dan kritis bergerak didalam menyuarakan perlindungan hak-hak anak. Apabila pemerintah ingin lebih berperan aktif, sudah saatnya Pemerintah Daerah juga punya lembaga sendiri berdasarkan amandat dari UU Perlindungan Anak, yang nantinya fokus mengawasi dan menjamin perlindungan hak anak.

Dasar dari pelaksanaan perlindungan hak anak ini oleh Pemerintah Daerah adalah (Indoenesia 2012): a) Dasar Filosofis, Pancasila dasar kegiatan dalam berbagai bidang kehidupan keluarga, bermasyarakat, bernegara, dan berbangsa, dan dasar filosofis pelaksanaan perlindungan anak; b) Dasar Etis, pelaksanaan perlindungan anak harus sesuai dengan etika profesi yang berkaitan, untuk mencegah perilaku penyimpangan dalam pelaksanaan kewenagan, kekuasaan, dan kekuatan dalam pelaksanaan perlindungan anak; c) Dasar Yuridis, pelaksanaan perlindungan hak anak harus didasarkan pada UUD 1945 dan berbagai peraturan perundang-undangan lainnya yang berlaku. Penerapan dasar yuridis ini harus secara integratif, yaitu penerapan terpadu menyangkut peraturan perundang-undangan dari berbagai hukum yang berkaitan. Dengan adanya dasar perlindungan hak anak ini, maka Pemerintah Daerah dalam membentuk Komisi Perlindungan Anak Daerah sudah seharusnya terbantu, karena ini dijadikan landasan untuk bergerak dalam menyuarakan perlindungan-perlindungan hak anak di daerah. 
3. Gagagasan Perlindungan Anak Yang Berkelanjutan

Penanaman pemahaman perlindungan anak berkelanjutan sangatlah perlu diajarkan secara dini kepada masyarakat. Karena dengan adanya penanaman pemahaman perlindungan anak berkelanjutan membuat perlindungan ini tidak berhenti ketika ada kasus-kasus anak yang sedang hangat diperbincangkan, lebih jauh dari itu hal ini berpengaruh pada implementasi undangundang perlindungan anak (Samsudi 2017) yang ada bisa dilaksanakan oleh setiap orang, aparat penegak hukum, dan pihak-pihak terkait yang disebutkan dalam undangundang perlindungan anak secara berkelanjutan (the best life to children).

Meratifikasi Konvensi Hak Anak melalui Keputusan Presiden Nomor 36 Tahun 1990, dan mengimplementasikan hak-hak anak tersebut, secara kuantitatif ada 40 (empat puluh) kewajiban negara peserta untuk mengimplementasikan hak-hak anak. Selain itu ada 4 macam penanaman hak-hak anak yaitu: 1) hak atas kelangsungan hidup (survival rights); 2) hak atas perlindungan (protection rights); 3) hak atas perkembangan (development rigths); dan 4) hak untuk berpartisipasi (participation rights).

Penanaman prinsip perlindungan anak harus menanamkan hal berikut ini: 1) Anak tidak dapat berjuang sendiri, merupakan salah satu prinsip yang digunakan dalam perlindungan anak adalah: anak itu modal utama kelangsungan hidup manusia, bangsa, dan keluarga, untuk itu hak-haknya harus dilindungi, anak tidak dapat melindungi sendiri hak-haknya, banyak pihak yang mempengaruhi kehidupannya. Negara, dan masyarakat berkepentingan untuk mengusahakan perlindungan hak-hak anak; 2) Kepentingan terbaik bagi anak (the best interst of the child), agar perlindungan anak dapat diselenggarakan dengan baik, dianut prinsip yang menyatakan bahwa kepentingan terbaik anak harus dipandang sebagai of paramount importaence (memperoleh prioritas tinggi) dalam setiap keputusan yang menyangkut anak, tanpa prinsip ini perjuangan untuk melindungi anak akan mengalami banyak sandungan, prinsip the best interest of the child digunakan karena dalam banyak hal anak korban, disebabkan ketidaktahuan anak, maka masyarakat menciptakan monster-monster yang lebih buruk di kemudian hari; 3) Pendekatan daur kehidupan (life-circle approach), perlindungan anak mengacu pada pemahaman bahwa perlindungan anak harus dimulai sejak dini, dan terus menerus. Janin yang berada dalam kandungan perlu dilindungi dengan gizi, termasuk yodium, dan kalsium yang baik melalui ibunya. Jika ia telah lahir, maka diperlukan air susu ibu (ASI), dan pelayanan kesehatan primer dengan memberikan pelayanan imunisasi, dan lain-lain, sehingga anak terbebas dari berbagai kemungkinan cacat, dan penyakit, masa-masa prasekolah, dan sekolah, diperlukan keluarga, lembaga pendidikan, dan lembaga sosial/keagamaan yang bermutu. Anak memperoleh kesempatan belajar yang baik, waktu istirahat, dan bermain yang cukup, dan ikut menentukan nasibnya sendiri. Pada saat anak sudah berumur 15-18 tahun, ia memasuki masa transisi dalam dunia dewasa. Periode ini penuh risiko karena secara kultural, seseorang akan dianggap dewasa, dan secara fisik memang telah cukup sempurna untuk menjalankan fungsi reproduksinya, pengetahuan yang benar tentang reproduksi, dan perlindungan dari berbagai diskriminasi, dan perlakuan salah, dapat memasuki perannya sebagai orang dewasa yang berbudi, dan bertanggung jawab. Perlindungan hakhak mendasar bagi pradewasa juga diperlukan agar generasi penerus, tetap bermutu, orang tua yang terdidik mementingkan sekolah anak-anak mereka, orang tua yang sehat jasmani, dan rohaninya, selalu menjaga tingkah laku kebutuhan, baik fisik maupun emosional anak-anak mereka; dan 4) Lintas sektoral, nasib anak tergantung dari berbagai faktor, baik yang makro maupun mikro, yang langsung maupun tidak langsung, kemiskinan, perencanaan kota, dan segala penggusuran, sistem pendidikan yang menekankan hafalan, dan bahan-bahan yang tidak relevan, komunitas yang penuh dengan ketidakadilan, dan sebagainya tidak dapat ditangani oleh sektor, terlebih keluarga atau anak itu sendiri, perlindungan terhadap anak adalah perjuangan yang membutuhkan sumbangan semua orang di semua tingkatan.

Asas hak hidup, kelangsungan hidup, 
dan perkembangan adalah hak asasi yang paling mendasar bagi anak yang dilindungi oleh negara, pemerintah, masyarakat, keluarga, dan orang tua. Asa ini memberikan gambaran bahwa hak hidup, kelangsungan hidup, dan perkembangan merupakan hakhak anak yang paling utama untuk dilindungi (Robet 2014). Asas penghargaan atas pendapat anak adalah penghormatan atas hakhak anak untuk berpartisipasi, dan menyatakan pendapatnya dalam pengambilan keputusan terutama jika menyangkut hal-hal yang mempengaruhi kehidupannya. Asas ini bermaksud untuk mendorong partisipasi anak dalam pemenuhan haknya dalam melaksanakan segala tindakan yang diambil dalam kehidupan si anak dengan meliputi: 1) hak untuk berpendapat, dan memperoleh pertimbangan atas pendapatnya; 2) hak untuk mendapat, dan mengetahui informasi serta untuk mengekspresikan; 3) hak untuk berserikat menjalin hubungan untuk bergabung; dan 4) hak untuk memperoleh informasi yang layak, dan terlindungi dari informasi yang tidak sehat.

Tanggal 20 November 1959 Sidang Umum Perserikatan Bangsa-Bangsa (PBB) telah mengesahkan Deklarasi tentang HakHak Anak. Dalam Mukadimah Deklarasi ini, tersirat bahwa umat manusia berkewajiban memberikan yang terbaik bagi anak-anak. Hal ini merupakan penanaman prinsip perlindungan anak yang sudah lama digagaskan secara universal, dan harusnya berlaku di seluruh dunia untuk penegakan hukum perlindungan anak. Deklarasi ini memuat 10 (sepuluh) asas tentang hak-hak anak (Manusia and Manusia 2008), yaitu: 1) Anak berhak menikmati semua hak-haknya sesuai dengan ketentuan yang terkandung dalam deklarasi ini. Setiap anak tanpa pengecualian harus dijamin hak-haknya tanpa membedakan suku bangsa, warna kulit, jenis kelamin, bahasa, agama, pandangan politik, kebangsaan, tingkatan sosial, kaya miskin, kelahiran atau status lain, baik yang ada pada dirinya maupun pada keluarganya; 2) Anak berhak memperoleh perlindungan khusus, dan harus memperoleh kesempatan yang dijamin oleh hukum, dan sarana lain, agar menjadikannya mampu untuk mengembangkan diri secara fisik, kejiwaan, dan moral, mampu untuk mengembangkan diri secara fisik, kejiwaan, moral, spiritual, dan kemasyarakatan dalam situasi yang sehat, normal sesuai dengan kebebasan, dan harkatnya. Penuangan tujuan itu ke dalam hukum, kepentingan terbaik atas diri anak harus merupakan pertimbangan utama; 3) Anak sejak dilahirkan berhak akan nama, dan kebangsaan; 4) Anak berhak, dan harus dijamin secara kemasyarakatan untuk tumbuh, dan kembang secara sehat. Untuk ini baik sebelum maupun setelah kelahirannya harus ada perawatan, dan perlindungan khusus bagi anak, dan ibunya. Anak berhak mendapat gizi yang cukup, perumahan rekreasi, dan pelayanan kesehatan; 5) Anak yang cacat fisik, mental, dan lemah kedudukan sosialnya akibat keadaan tertentu harus memperoleh pendidikan, perawatan, dan perlakuan khusus; 6) Agar kepribadian anak tumbuh secara maksimal, dan harmonis, ia memerlukan kasih sayang, dan pengertian. Sedapat mungkin ia harus dibesarkan di bawah asuhan, dan tanggungjawab orang tuanya sendiri, dan bagaimanapun harus diusahakan agar tetap berada dalam suasana yang penuh kasih sayang, sehat jasmani, dan rohani. Anak di bawah usia 5 (lima) tahun tidak dibenarkan terpisah dari ibunya. Masyarakat, dan pemerintah yang berwenang berkewajiban memberikan perawatan khusus kepada anak yang tidak memiliki keluarga, dan kepada anak yang tidak mampu. Diharapkan agar pemerintah atau pihak lain memberikan bantuan pembiayaan bagi anakanak yang berasal dari keluarga besar; 7) Anak berhak mendapat pendidikan wajib secara gratis sekurang-kurangnya pada tingkat pendidikan dasar. Mereka harus mendapat perlindungan yang dapat meningkatkan pengetahuan umumnya, dan yang memungkinkan atas dasar kesempatan yang sama untuk mengembangkan kemampuannya, pendapat pribadinya, dan persaan tanggungjawab moral, dan sosialnya, sehingga mereka dapat menjadi anggota masyarakat yang berguna. Kepentingan anak haruslah dijadikan pedoman oleh mereka yang bertanggungjawab terhadap pendidikan, dan bimbingan anak yang bersangkutan: pertama-tama tanggung jawab tersebut terletak pada orang tua mereka. Anak harus mempunyai kesempatan yang leluasa untuk bermain, dan berekreasi yang diarahkan 
untuk tujuan pendidikan, masyarakat, dan pemerintah yang berwenang harus berusaha meningkatkan pelaksanaan hak ini; 8) Dalam keadaan apapun anak harus didahulukan dalam menerima perlindungan, dan pertolongan; 9) Anak harus dilindungi dari segala bentuk kealapaan, kekerasan, dan eksploitasi. Ia tidak boleh dijadikan subjek perdagangan. Anak tidak boleh bekerja sebelum usia tertentu, ia tidak boleh dilibatkan dalam pekerjaan yang dapat merugikan kesehatan atau pendidikannya, maupun yang dapat mempengaruhi perkembangan tubuh, jiwa, dan akhlaknya; dan 10) Anak harus dilindungi dari perbuatan yang mengarah ke dalam bentuk diskriminasi sosial, agama maupun bentuk-bentuk diskriminasi lainnya. Mereka harus dibesarkan di dalam semangat penuh pengertian toleransi, dan persahabatan antarbangsa, perdamaian, serta persaudaraan semesta dengan penuh kesadaran bahwa tenaga, dan bakatnya harus diabadikan kepada sesama manusia(Handayani 2013).

Menurut penulis dari asas-asas perlindungan anak yang dikemukakan diatas, sudah dengan sangat gamblang menjelasakan mengenai gagasan penanaman pemahaman perlindungan anak berkelanjutan. Karena melalui hal-hal tersebut merupakan kunci penting dari agar perlindungan anak itu bisa berjalan secara berkelanjutan, dan tidak berhenti dengan adanya kepentingan dari segelintir orang, maupun karena topik perlindungan sangat menarik untuk diperbincangkan apabila kasus anak itu terjadi di suatu daerah Indonesia.

\section{Simpulan}

Peran Pemerintah Daerah didalam perlindungan anak sangatlah vital sekali. Ini sudah tertuang didalam pasal-pasal yang direvisi sudah menjelaskan bagaimana tanggung jawab dan kewajiban dari Pemerintah Daerah dalam melindungi hak anak. Didalam mewujudkan tata kelola pemenuhan hak anak oleh Pemerintah Daerah haruslah benar-benar direalisasikan dan dijalankan dengan semestinya. Kota Layak Anak merupakan impian dari setiap anak, karena anak akan dibesarkan secara layak dan semestinya, dan didalam pembentukan Komisi Perlindungan Anak Daerah,
Pemerintah Daerah harus terlihat sungguhsungguh dalam mengelola ini, jangan sampai Komisi Perlindungan Anak Daerah ini hanya tertuang didalam UU Perlindungan Anak saja, tanpa ada realisasinya dari Pemerintah Daerah. Pemerintah Daerah sebagai pemerintah yang bersentuhan lansung dengan kehidupan anak terlebih dahulu harusnya lebih aktif dan lebih kritis, untuk menyuarakan hak-hak anak dan wajib untuk memenuhi dan melindungi hak anak dari pihak-pihak yang nantinya merugikan perkembangan hak anak dalam mencapai kedewasaannya. Melindungi anak didalam perkembangannya sampai dewasanya kelak, sudah sepatutnya Pemerintah mengalokasikan dana APBD secara khusus, untuk membantu peran aktif Pemerintah Daerah terhadap perlindungan anak. Menata kelola pemenuhan hak anak oleh Pemerintah Daerah, sudah seharusnya pemerintah daerah membangun sebuah lembaga sendiri yang fokus untuk melindungi, menjaga, memantau dan mengawasi hak anak. Seperti amandat dari UU Perlindungan Anak bahwa daerah bisa memiliki Komisi Perlindungan Anak Daerah. Pemerintah Daerah dapat bekerja sama dengan Lembaga Sosial yang fokus menyuarakan hak-hak anak, agar bisa memantau perkembangan perlindungan anak di daerah, bahkan sampai didaerah terpencil sekalipun, yang sulit dijangkau. Untuk mewujudkan Kota Layak Anak, Pemerintah Daerah haruslah mempunyai komitmen yang kuat untuk mewujudkan ini, karena apabila hal ini telah terealisasi, maka perkembangan anak semakin bagus dan menjadi seorang dewasa yang kelak berguna bagi dirinya sendiri, Keluarga, Orang Tua, Masyarakat, Pemerintah Daerah dan Negara. Terakhir, penanaman pemahaman perlindungan anak berkelanjutan sangatlah perlu diajarkan sejak dini kepada masyarakat, karena apabila sejak dini masyarakat diajarkan memahami perlindungan anak secara berkelanjutan, maka perlindungan anak di Indonesia tidak akan berhenti.

\section{DAFTAR PUSTAKA}

Adam, E Prajwalita Widiati \& Haidir. 2012. "Pengawasan Terhadap Peraturan Kepala Daerah."Yuridika 27(1): 7795. 
Ardhyanto, Ryan Chandra. 2015. "Optimalisasi Peran KPAI Sebagai Bentuk State Auxiliary Organs Dalam Perlindungan Anak Terlantar." Uiversitas Islam Negeri Syarif Hidayatullah.

Ardiansyah, Ferdricka Nggeboe, Abdul Hariss. 2015. "Kajian Yuridis Penelantaran Anak Oleh Orang Tua Menurut Persfektif Hukum Indonesia." Jurnal Legalitas VII(1): 98144.

Arliman, Laurensius. 2017. "Perlindungan Anak Oleh Masyarakat Ditinjau Dari Mazhab Sejarah Di Dalam Penerapan Prinsip The Best Interest Of The Child Pada Kehidupan Anak Di Indonesia." Era Hukum 2(1): 12349.

Asshiddiqie, Jimly. 2006. Pengantar Ilmu Hukum Tata Negara. Jakarta: Sekretariat Jenderal dan Kepaniteraan Mahkamah Konstitusi Republik Indonesia.

Bedner, Adriaan W, Sulistyowati Irianto, Jan Michiel Otto, and Theresia Dyah Wirastri. 2012. Kajian Sosio - Legal. Denpasar: Pustaka Larasan.

Fahmiron. 2017. Pertimbangan Hakim Dalam Perampasan Aset Koruptor (Dalam Perspektif Perlindungan Hak Anak). Jakarta: Rajawali Press.

Fauzan, Muhammad. 2010. "Eksistensi Komisi Negara Dalam Sistem Ketatanegaraan Republik Indonesia (Studi Terhadap Komisi Perlindungan Anak Indonesia)." Media Hukum 17(2): 298312.

Halili. 2015. Hak Asasi Manusia: Dari Teori Ke Pedagogi. 1st ed. Yogyakarta: Fakultas Ilmu Sosoal Universitas Negeri Yogyakarta.

Handayani, I Gusti Ayu Ketut Rachmi. 2013. "Urgensi Perlindungan Anak Di Indonesia (Kajian Perspektif Hukum)." Bestuur 2: 514.

Hidayati, Nur. 2014. "Perlindungan Anak Terhadap Kejahatan Kekerasan Seksual (Pedofilia)." Jurnal Pengembangan Humaniora 14(1): 6873. http://jurnal. polines.ac.id/j urnal/index.php/ragam /article/ view/496.

Indoenesia, Kementerian Agama Republik. 2012. Bersatu Mewujudkan Indonesia Ramah Anak. Jakarta: Kementerian
Agama Republik Indoenesia.

Kurniawan, Robi Cahyadi. 2016. "Inovasi Kualitas Pelayanan Publik Pemerintah Daerah." Fiat Justisia Journal of Law 10(3): 56986 . http://jurnal. fh.unila.ac.id/index.php/fiat.

Manusia, Equitas dan Direktorat Jenderal Hak Asasi Manusia dan Departemen Hukum Hak Asasi, and Manusia. 2008. Memperkuat Perlindungan Hak Asasi Manusia Di Indonesia. 1st ed. Jakarta: Equitas dan Direktorat Jenderal Hak Asasi Manusia dan Departemen Hukum Hak Asasi Manusia Manusia.

Qamar, Nurul. 2015. Pengantar Hukum Tata Negara. Makasar: Arus Timur.

Rezah, Nurul Qamar dan Farah Syah. 2015. Ilmu Kenegaraan (Staatswissenschaft). Jakarta: Mitra Wacana Media.

Robet, Robertus. 2014. Politik Hak Asasi Manusia Dan Transisi Di Indonesia. Jakarta: Lembaga Studi dan Advokasi Masyarakat (ELSAM).

Rochaeti, Nur. 2015. "Implementasi Keadilan Restoratif Dan Pluralisme Hukum Dalam Sistem Peradilan Pidana Anak Di Indonesia." Masalah-Masalah Hukum 44(2): 15060.

S, Laurensius Arliman. 2017. "UndangUndang Nomor 17 Tahun 2016 Tentang Penetapan PERPPU 1 Tahun 2016 Sebagai Wujud Perlindungan Anak Ditinjau Dari Perspektif Hukum Tata Negara." Jurnal Hukum Positum 1(2): 16998.

Samsudi, Y.A. Triana Ohoiwutun \&. 2017. "Penerapan Prinsip Kepentingan Terbaik Bagi Anak Dalam Kasus Tindak Pidana Narkotika." Yudisial 10(1): 3957.

Statistik, Kementerian Pemberdayaan Perempuan dan Perlindungan Anak serta Badan Pusat Statistik dengan Badan Pusat. 2015. Profil Anak Indonesia 2015. Jakarta: Kementerian Pemberdayaan Perempuan dan Perlindungan Anak serta Badan Pusat Statistik dengan Badan Pusat Statistik.

Widiantari, Kadek. 2017. "Perlindungan Hukum Terhadap Anak Yang Berkonflik Dengan Hukum Yang Dijatuhi Pidana Pelatihan Kerja." Masalah-Masalah Hukum 46(4): 299307. 